\title{
Evaluation of Wastewater Quality Compared to Well Water in Irrigation
}

\author{
Rahim Alimohammadi Nafchi \\ Agricultural Engineering Research Department, Chahrmahal and Bakhtiari Agricultural and Natural Resources Research and \\ Education Centre, AREEO, Shahrekord, Iran \\ Email: nafchi38@gmail.com
}

How to cite this paper: Nafchi, R.A. (2017) Evaluation of Wastewater Quality Compared to Well Water in Irrigation. Open Journal of Ecology, 7, 271-278.

https://doi.org/10.4236/oje.2017.74018

Received: May 19, 2016

Accepted: April 17, 2017

Published: April 20, 2017

Copyright (c) 2017 by author and Scientific Research Publishing Inc. This work is licensed under the Creative Commons Attribution International License (CC BY 4.0).

http://creativecommons.org/licenses/by/4.0/

\begin{abstract}
Water resources' scarcity and increasing demand for water consumption have necessitated the use of unconventional water for optimized and sustainable consumption of water resources. The present project ${ }^{1}$ was conducted to investigate effects of domestic wastewater in comparison to well water, in a randomized complete block design with four treatments in three replications during three years. Concentrations of cations and anions in soil and plants as well as plants' fresh and dry weight were measured in the present research per harvesting time. Results showed that the concentration of elements in alfalfa was higher in treatments being irrigated with wastewater resulting in the significant differences in nitrogen, phosphorus, sodium and chloride. The mean of elements' concentration at soil with the depth of $0-30 \mathrm{~cm}$ in wastewater treatments was much more than those treatments irrigated with groundwater. Concentrations of elements in wastewater treatment with the depth of $30-60$ $\mathrm{cm}$ were higher than well water treatments. Electrical conductivity, $\mathrm{pH}$, total nitrogen, copper and iron significantly differed in different years and different treatments. Treatments irrigated with wastewater showed higher yield compared to treatments irrigated with well water $(29,158$ and $1252.5 \mathrm{~kg}$ per ha). Using wastewater of domestic treatment plant increased production per unit area and subsequently increased elements concentration in soil and plant.
\end{abstract}

\section{Keywords}

Elements Concentration in Soil and Plant, Irrigation, Reusing

Wastewater of Domestic Treatment Plant

\section{Introduction}

Increasing demand for water consumption results in lower per capita water; this

${ }^{1}$ Reusing treatment plant wastewater in lands irrigation and evaluating resulting changes in soil and plants. Research Institute of Agricultural Engineering, registration number 85/796 and 55 p. 
problem will be a serious threat to human society in case of poor water sustainable management and optimization for demand-supply and lack of high-productive varieties as well as draught resistant varieties. Population growth, increasing per capita water consumption, converting consumed water to wastewater and generation of huge amount of wastewater in all communities require sustainable programs for optimum use of such water resources. According to Statistics Center of Iran, Iran's population were over 75 million people in 2011. Assuming that 70 percent of Iran's population is living in cities and per capita consumption is 200 liters per day, the volume of consumed water will be 3.84 billion cubic meters per year, and assuming that it is collected and treated by 65 percent, then an amount of 2.5 billion cubic meters wastewater will be obtained for irrigation. One of the issues in the modern societies concerned the increase in production and consumption of chemicals in different processes. Irrigation with wastewater caused an increase in sugar beet yield compared to well water. The difference was significant [1]. Surface soil analysis $(0-30 \mathrm{~cm})$ in Mashhad showed that irrigation with wastewater increased saturated electrical conductivity, total nitrogen, phosphorus, and heavy metals in the soil solution [2]. The value of protein, phosphorus and potassium consultations, measured in crop irrigated with wastewater, was higher than that in the crop irrigated with well water [3]. The value of municipal treatment plant wastewater generated during critical periods of year, when demand for the use of water in agriculture while being increased was high. So reusing wastewater of mentioned treatment plant is one of the most useful ways to prevent environmental pollution and to supply a percentage of water demand of lands located in arid areas [4]. In a study conducted in Shahinshar, Iran, the authors concluded that irrigation with municipal treatment plant wastewater significantly increased the yield of irrigated wheat and water use' efficiency compared to well water treatment [5]. Using wastewater for broccoli irrigation in Shiraz, Iran, Research Station significantly increased fresh weight, biological yield, potassium, calcium, phosphorus and chlorine at the level of 5\% compared to treatment with well water [6]. In corn irrigation with municipal treatment plant wastewater, researchers reported that wastewater treatments led to the higher yield compared to well water (dry matter, biomass, grain) and at the same time water use' efficiency was increased [7]. Macro and micro pores of soil were increased as results of irrigation with wastewater. The concentrations of $\mathrm{P}$ and $\mathrm{Br}$ in these soils were increased slightly [8]. Security of crop water requirement was ensured by reusing treatment plant wastewater and special irrigation management [9]. Long-term using of wastewater for irrigation reduced soil acidity and such reductions were significant in periods of 3, 8 and 20 years at probability level of 5 percent, so that it finally affected sustainable utilization [10]. Irrigation with wastewater in Crete Island of Greece led to considerable fresh water saving in hot seasons; however, qualitative investigation showed that long term irrigation by wastewater declined soil quality [11]. Implementing the project of reusing water and wastewater during 4 years in Tunisia, the researchers concluded that the amounts of sodium absorption ratio, or- 
ganic materials of soil and electrical conductivity were increased significantly, but $\mathrm{pH}$ and infiltration rate were reduced [12]. Netzer, et al., examined the effects of water and wastewater on vineyards during 6 seasons in southern Israel in the Kurd semi-arid region. They concluded that the increased irrigation with waste-water led to the increased sodium and sodium adsorption ratio [13]. Comparing plants yield and soil properties being irrigated with well water and wastewater in southwestern Nigeria, they concluded that using wastewater increased amounts of potassium, calcium, sodium absorption ratio (SAR), as well as yield and soil fertility [14]. Increasing population growth, transformation of the villages into the cities, and migration from villages to cities are factors involved in the development of cities and urbanization [14]. Construction of collection and disposal of domestic wastewater networks were preconditions of human societies and governments have seriously spent a lot of money on this issue. Wastewater, generated during the year, is one of the sustainable, secure and available resources supplied and produced continuously. Therefore, this project was implemented to prevent environmental pollution, optimal use of these resources, and the impact of domestic treatment plant wastewater on soil and plant, so that; a balance between water supply and demand is established.

\section{Materials and Methods}

The project was carried out for three years (2001-2003) at Agricultural Research Station of Chahartkheth, being located in Shahrekord, southwest of Iran. According to Kopen method, climate of the stations is characterized as cold while having hot and arid summer. The average annual precipitation, average relative humidity, daily mean temperature and annual evaporation are $295 \mathrm{~mm}, 41.7$ percent, 12.2 degree centigrade and $1710 \mathrm{~mm}$, respectively. Soil texture in the site of implementing of project was clay loam with relatively low permeability with field capacity of 37 percent. This experiment was carried out at randomized complete block design with four treatments and three replications. Irrigation treatments were used by two types of water namely; (well water) and wastewater as follows. Treatment I: Irrigation with well water and farmer practices. Treatment II: Irrigation with treatment plant wastewater and farmer practices. Treatment III: Irrigation with well water and calculated water. Treatment IV: Irrigation with wastewater and required water. Cropwat software and FAO 24 journals were used in order to calculate required water evapotranspiration and water requirements in the third and fourth treatments. To apply irrigation treatments, well water was used for the first and third treatments and wastewater from Shahrekord plant treatment was used in the second and third treatments. Also well water and wastewater volume entering each plot at each step was measured by installing two-inch meters contours. At the end of each harvest, samples were taken from soil (at depths of $0-30$ and $30-60 \mathrm{~cm}$ ) and each plot's plants to determine required parameters as well as measuring fresh and dry weight. Data were analyzed using SAS software and means were compared using Duncan's multiple range test. 


\section{Discussion and Results}

Figure 1 illustrated the results of mean comparison for treatments of irrigation by farmer practice and irrigation by water. Forage wet and dry yield in foregoing treatments did not differ significantly, but content treatments of calculated water showed higher yield. Forage yield in irrigation treatments with wastewater and well water suggests that irrigation with wastewater was more productive and this difference was significant at probability level of 5 percent (Figure 2). The water volume, which consumed per plot, according to farmers' practice, was 18,700 liters per year. However, the volume of water used in plots 3 and 4 on calculated required water was 14027 liters per year and being equal to 75 percent of farmers' practice. Treatments 4 and 2 had higher yield and were significant at probability level of 5 percent, compared to other treatments. As a whole, treatment 4 showed higher yields. Alfalfa forage yield in the combined variance analysis showed that among different years of conducting projects since 2000-2002, treatments and interaction of treatments were significant at probability level of 1 percent of Duncan's multiple range test (MRT); however, there were no significant difference between replications. Nitrogen content in different treatments at a probability level of 1 percent of MRT showed significant differences. P percent differed significantly only in treatments (at probability level of 1 percent) and interaction of treatment within a year (at probability level of 5 percent). The amount of calcium and magnesium, were significantly different in different years and at

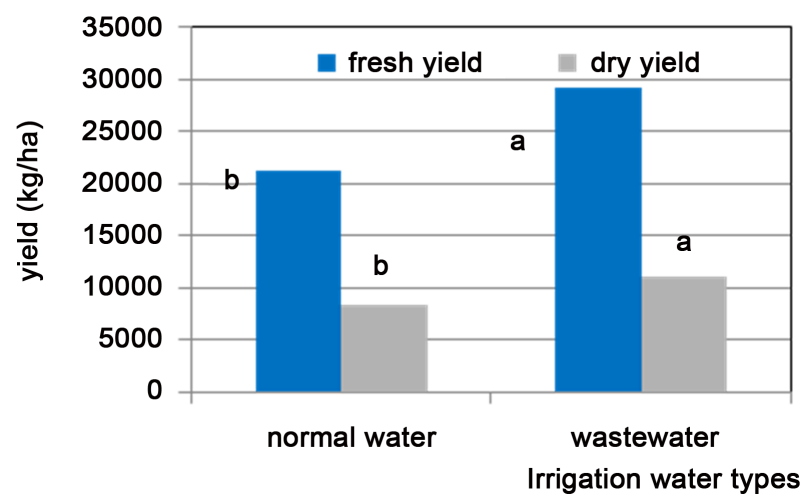

Figure 1. Yields mean based on irrigation type.

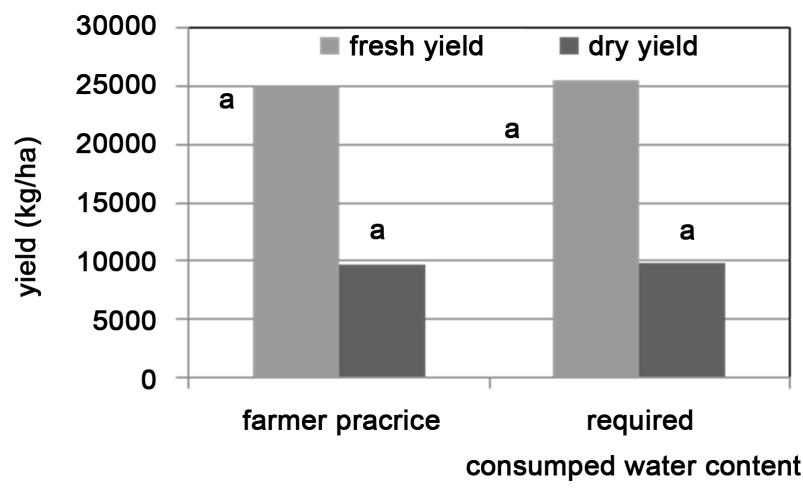

Figure 2. Mean of yields based on water consumption rate. 
a probability level of 1 percent. Only in interaction with the treatments, they showed significant differences at a probability level of 5 percent. The amount of manganese and copper in different years were significantly different at a probability level of 1 percent. Fresh and dry yields of forage in treatments 1 and 3 were significantly different at a probability level of 5\%, using well water to the wastewater treatment 2 and 4 . The yield of treatments using wastewater with the value of calculated water (required by plant) was higher than farmers' practice. The results shown in Figure 2 indicated that treatments 2 and 4 were significantly different from treatments 1 and 3 in terms of fresh forage and dry forage yield. Using wastewater increased fresh and dry forage yield. Forage yield in water and wastewater treatment shown in Figure 1 was related to lack of significant differences in the water; Figure 2 was related to the significant differences in consumed water (well water and wastewater); therefore, it confirms the above-mentioned cases. The results have corresponded with the research results of other researchers [1] [9] [15].

Table 1 the effects of using well water and wastewater on the concentration of nutrient accumulation in alfalfa were as follows: potassium, calcium, magnesium, iron, manganese, zinc, and copper; when comparing with well water relating to treatment plant, wastewater has not significant differences in alfalfa plant. Nitrogen, phosphorus, sodium and chlorine were significantly different; usually the concentrations of elements in wastewater treatment were much more than those of well water. Comparison the means of concentrations of some elements in depth of $0-30 \mathrm{~cm}$ such as chlorine as well as the saturation percentage did not show any significant differences in different years. In addition, saturation percent among the years showed significant difference at a probability level of 1 percent; however, it showed no significance among treatments. The yield of treatment 4 was higher than other treatments. Electrical conductivity between years and treatments at a probability level of 1 percent indicated a significant difference resulting in the higher concentrations of treatments $2,1,4$ and 3 , respectively. Acidity was significantly different in various years and treatments. Organic carbon content in different years was significantly different. Phosphorus and treatments in different years, at a probability level of 1percent through Duncan multiple range test showed significant differences. However, sodium, calcium, magnesium, bicarbonate and copper during years as well as the treatments were significantly different at a probability level of 1 percent (Table 2). Comparison of the means of some elements' concentrations in depths of (30 $60) \mathrm{cm}$ at a probability level of 1 percent in Duncan multiple range test were as

Table 1. Effect of water and wastewater of treatment plant on concentration of some nutritional elements in alfalfa (2000-2002).

\begin{tabular}{|c|c|c|c|c|c|c|c|c|c|c|c|c|}
\hline \multirow{2}{*}{ Water type } & \multicolumn{12}{|c|}{ Elements } \\
\hline & $\mathrm{Cl}$ & $\mathrm{Na}$ & $\mathrm{B}$ & $\mathrm{Cu}$ & $\mathrm{Zn}$ & $\mathrm{Mn}$ & $\mathrm{Fe}$ & $\mathrm{Mg}$ & $\mathrm{Ca}$ & $\mathrm{K}$ & $\mathrm{P}$ & $\mathrm{N}$ \\
\hline Normal water & $5867 \mathrm{~b}$ & $494 \mathrm{~b}$ & $103 \mathrm{a}$ & $19.9 \mathrm{a}$ & $20.6 \mathrm{a}$ & $65.9 \mathrm{a}$ & $474.9 \mathrm{a}$ & $0.25 \mathrm{a}$ & $1.96 \mathrm{a}$ & $2.2 \mathrm{a}$ & $0.26 \mathrm{~b}$ & $3.54 \mathrm{~b}$ \\
\hline Wastewater & 6799 a & $645 \mathrm{a}$ & $104 \mathrm{a}$ & $18.6 \mathrm{a}$ & $21.3 \mathrm{a}$ & $71.7 \mathrm{a}$ & $529.7 \mathrm{a}$ & $0.26 \mathrm{a}$ & $1.95 \mathrm{a}$ & $2.5 \mathrm{a}$ & $0.27 \mathrm{a}$ & $3.60 \mathrm{a}$ \\
\hline
\end{tabular}

Mean in each column by the same letters are not significantly different at $5 \%$ probability level using Duncan's multiple range test. 
Table 2. Comparison means comparison of some elements concentration at depth $0-30 \mathrm{~cm}$ in Duncan multiple range tests at $1 \%$ probability level.

\begin{tabular}{|c|c|c|c|c|c|c|c|c|c|c|c|c|c|c|}
\hline \multirow{3}{*}{ Year } & \multicolumn{14}{|c|}{ Elements } \\
\hline & \multicolumn{4}{|c|}{$\begin{array}{c}\text { Micronutrients } \\
\text { absorbed } \\
\mathrm{mg} \cdot \mathrm{kg}^{-1}\end{array}$} & \multicolumn{4}{|c|}{$\begin{array}{c}\text { Soluble anions } \\
\text { and cations mg.lit }\end{array}$} & \multirow{2}{*}{$\begin{array}{c}\text { Total } \\
\text { nitrogen } \\
\% \\
\text { Total N }\end{array}$} & \multirow{2}{*}{$\begin{array}{c}\begin{array}{c}\text { Exchangeable } \\
\text { potassium }\end{array} \\
\begin{array}{c}\mathrm{mg} \cdot \mathrm{kg}^{-1} \\
\text { K.ave }\end{array}\end{array}$} & \multirow{2}{*}{$\begin{array}{c}\text { Exchangeable } \\
\text { phosphore }\end{array}$} & \multirow{2}{*}{$\begin{array}{c}\text { O. C. } \\
\quad \%\end{array}$} & \multirow{2}{*}{$\mathrm{pH}$} & \multirow{2}{*}{ S.P } \\
\hline & $\mathrm{Fe}$ & $\mathrm{Mn}$ & $\mathrm{Zn}$ & $\mathrm{Cu}$ & $\mathrm{HCO}_{3}$ & $\mathrm{Cl}$ & $\mathrm{Ca}+\mathrm{Mg}$ & $\mathrm{Na}$ & & & & & & \\
\hline 2000-01 & $8.08 \mathrm{a}$ & $8.15 \mathrm{~b}$ & $0.657 \mathrm{l}$ & $1.76 \mathrm{~b}$ & $3.13 \mathrm{c}$ & $3.5 \mathrm{a}$ & $5.017 \mathrm{a}$ & $4.01 \mathrm{a}$ & $0.0696 \mathrm{a}$ & $290 \mathrm{~b}$ & $26.1 \mathrm{a}$ & $0.55 \mathrm{~b} \quad 27.76 \mathrm{a}$ & 8.07 a 0.602 b & $39 c$ \\
\hline 2001-02 & $7.37 \mathrm{~b}$ & $7.48 \mathrm{c}$ & 0.847 & $1.96 \mathrm{a}$ & $6.48 \mathrm{a}$ & $4.05 \mathrm{a}$ & $3.638 \mathrm{~b}$ & $3.157 \mathrm{~b}$ & $0.0667 \mathrm{~b}$ & $365.2 \mathrm{a}$ & $30.2 \mathrm{a}$ & $0.61 \mathrm{a} \quad 27.14 \mathrm{a}$ & 7.96 b $0.975 a$ & $44 \mathrm{~b}$ \\
\hline $2002-03$ & $7.76 \mathrm{ab}$ & $10.9 \mathrm{a}$ & 1.084 & $1.65 \mathrm{c}$ & $3.58 b$ & $3.6 \mathrm{a}$ & $5.033 \mathrm{a}$ & $2.719 c$ & $0.0717 \mathrm{a}$ & $248.3 \mathrm{~b}$ & $19.3 \mathrm{~b}$ & $0.57 \mathrm{ab} 27.04 \mathrm{a}$ & 7.86 c $0.624 b$ & $45 \mathrm{a}$ \\
\hline Treat 1 & $7.87 \mathrm{a}$ & $9.09 \mathrm{a}$ & 0.764 & $1.77 \mathrm{~b}$ & $4.49 \mathrm{ab}$ & $3.99 \mathrm{a}$ & $4.457 \mathrm{~b}$ & $2.508 \mathrm{~b}$ & $0.071 \mathrm{a}$ & $290.3 \mathrm{a}$ & $16.2 \mathrm{~b}$ & 0.555 a 27.29 a & 7.97 b $0.558 \mathrm{~b} 4$ & $43.04 \mathrm{a}$ \\
\hline Treat 2 & $7.85 \mathrm{a}$ & $8.79 \mathrm{a}$ & 0.867 & $1.79 \mathrm{a}$ & $4.07 \mathrm{~b}$ & $3.82 \mathrm{a}$ & $4.748 \mathrm{a}$ & $3.986 \mathrm{a}$ & $0.071 \mathrm{a}$ & $357.7 \mathrm{a}$ & $33.8 \mathrm{a}$ & 0.596 a 27.05 a & 7.96 b $0.907 \mathrm{a} 4$ & $42.22 \mathrm{a}$ \\
\hline Treat 3 & $7.33 \mathrm{a}$ & $8.54 \mathrm{a}$ & 0.853 & $1.76 \mathrm{a}$ & $4.16 \mathrm{~b}$ & $3.46 \mathrm{a}$ & $4.322 \mathrm{~b}$ & $2.529 \mathrm{~b}$ & $0.068 \mathrm{a}$ & $289.6 \mathrm{a}$ & $19.4 \mathrm{~b}$ & 0.599 a 27.61 a & $8.03 \mathrm{a} 0.524 \mathrm{~b} 4$ & $42.35 \mathrm{a}$ \\
\hline Treat 4 & $7.88 \mathrm{a}$ & $8.96 \mathrm{a}$ & 0.967 & $1.84 \mathrm{a}$ & $4.88 \mathrm{a}$ & $3.59 \mathrm{a}$ & $4.724 \mathrm{ab}$ & $4.158 \mathrm{a}$ & $0.067 \mathrm{a}$ & $315.1 \mathrm{a}$ & $31.4 \mathrm{a}$ & 0.562 a $27.31 \mathrm{a}$ & $7.94 \mathrm{~b} 0.947 \mathrm{a} 4$ & $43.06 \mathrm{a}$ \\
\hline
\end{tabular}

Mean in each column by the same letters are not significantly different at 1 percent probability level using Duncan's multiple range test.

follows; saturation, soil organic carbon, phosphorus, potassium, calcium, magnesium, chloride, bicarbonate, zinc and manganese showed no significant differences between treatments, but they showed significant differences in various years of performed project. Electrical conductivity, $\mathrm{pH}$, total nitrogen, copper and iron were significantly different in different years and between treatments. The amount of sodium was significantly different between treatments so that the concentration of treatment 4 was higher. Wastewater's $\mathrm{PH}$, calcium, magnesium, Chlorine, zinc, and manganese were found to be $7.97,49.46 \mathrm{mg}, 35.18,0.071$, $0.101 \mathrm{mg}$ per liter in wastewater samples, respectively. While sodium, copper and iron in treatments 3 and 4 (irrigation by water required for plant) have been increased. Plant usable copper was decreased as soil $\mathrm{pH}$ was increased and it is often stated that iron deficiency is associated mainly with high $\mathrm{pH}$, increased phosphorus in soil, increased lime and increased HCO3 in the root zone. The amount of absorbable potassium and total nitrogen were decreased in plant required water treatment at depth of $(30-60) \mathrm{cm}$.

\section{Conclusions}

$$
\begin{aligned}
& \text { استفاده از بِّاب تصفيه خانه هاى فاضلابخانكى هميشه بر اى بهره بردار ان با ريسك همر اه بوده است. }
\end{aligned}
$$



The use of the sewage of domestic waste water treatment plants has always been associated with risk for exploiters. The present project was implemented to answer these questions and reassure the farmers.

Alfalfa crops yield irrigated with wastewater showed higher yield when comparing with those irrigated with well water. The plots irrigated with required water (calculated) showed higher fresh and dry yield than plots irrigated with equivalent water in farmers' practice. In terms of plant dry and fresh yield, treatments showed no significant differences under different amounts of waste- 
water (irrigation water equivalent to farmer practice and amount of calculated water required by plants). However, yield of treatment 4 , irrigated through the use of wastewater of treatment plant required by plant, showed better yield compared to other treatments.

$$
\text { كه نتايج حاصل از يزو هش حسناقلى و همكار ان، هامورى و هاندوف (2002) مؤيد قضيه فوقالذكر است. }
$$

These results are in compatible with the results of Hassanoghli, et al., Hamouri and Handouf (1996) and Pereira and Owes (2002).

Treatments showed no significant differences regardless of water or wastewater, considering the plant's dry and fresh yield in treatments using farmers' practice and water required by plant,. However, treatments irrigated with plants required water with water and wastewater showed higher fresh and dry yield compared to other treatments (fresh yield of plant was increased by 2.8 percent and dry yield of plant was increased by 1.6 percent). Fresh and dry yield of plant in wastewater treatment was increased in a way that their yield was significantly different (fresh and dry yield were increased about 27 and 24 percent, respectively). The concentration of some nutrients in the soil's surface layer $(0-30 \mathrm{~cm})$ showed that treatments irrigated with wastewater (treatments 2 and 4) compared to treatments 1 and 3 (irrigated with well water) had much higher concentrations. Mean of concentrations of elements such as nitrogen, sodium, magnesia, manganese, copper, boron, iron, exchangeable potassium, at a depth of $30-60 \mathrm{~cm}$ in treatments of wastewater compared to well water were found to be higher. As a result, treatments with used of water requirement (calculated) and wastewater relating to the rest of the treatments were preferred having higher crop yield due to the higher amounts of nutrients in wastewater.

$$
\text { لذا نتايج حاصله با نتايج عرفانى و همكاران (2010) مطابقت دارد. }
$$

Therefore, the results are consistent with the results of Erfani and colleagues (2010), Chow, et al. (1985) and Xu, et al. (2010).

\section{Acknowledgements}

This work was carried out in Chaharmahal and Bakhtiari Agricultural and Natural Resources Research and training Center, Chahartakhteh station. Thanks to Dr. Ali Morshedi, Mr. Esmaeil Salimi and Alireza Hashemi for their participation and support in this study.

\section{References}

[1] Valinejad, M. (2001) Effects of Sprinkler Systems and Surface Water and Soil on Yield of Crops. Master Thesis, Isfahan University of Technology, Isfahan.

[2] Erfani, A., Haghnia, G.H. and Alizadeh, A. (2002) The Effect of Irrigation with Wastewater on Yield and Quality of Lettuce and Soil Properties. Journal of Science and Engineering Agriculture and Natural Resources, N 1.

[3] Hassanoghli, A., Mirabzadh, M. and Liaghat, A. (2004) Effects of Irrigation with Domestic Wastewater on Yield of Some Vegetables and Nutrients (N, P, K). 3 rd National Conference on Application of Biological Development and Efficient Use of 
Fertilizers and Pesticides in Agriculture, Karaj.

[4] Alimohammadi, R. (2006) Reusing Treatment Plant Wastewater in Irrigation Water and the Resulting Changes in Soil and Plants. Agricultural Engineering Research Institute, 796, 85-55.

[5] Najafi, P., Mousavi, Q.F. and Feizi, M. (2007) Effects of Treated Wastewater on Yield and Quality of Wheat. Journal of Soil and Water Sciences, 21, 236-227.

[6] RajabiSorkhni, M. and Ghaemi, A.A. (2002) Effects of Application of Treated Wastewater and Fertilizers on Broccoli Yield. Land and Water Management, 2, 2413.

[7] Alinejadian, A. and Maleki, A. (2013) Evaluation of Water Use Efficiency and Yield of Maize in Urban Wastewater in an Area with Cold Dry Climate. 1st National Conference on the Challenges of Water Resources and Agriculture, Irrigation and Drainage Board, Isfahan, 24 February 2013, 8 p.

[8] Chow, V.T., Eliassen, R. and Linsley, K. (1985) Wastewater Engineering Treatment Disposal Reuse. McGraw-Hill, New York.

[9] Pereira, L.S. and Owes, T. (2002) Irrigation Management under Wader Water Scarcity. Water Management, 57, 175-206.

[10] Xu, J., Wu, L., Chag, A.C. and Zhang, Y. (2010) Impact of Long-Term Reclaimed Wastewater Irrigation on Agricultural Soils: A Preliminary Assessment. Journal of Hazardous Materials, 183, 780-786.

[11] Agrafioti, E. and Diamadopoulos, E. (2012) A Strategic Plan for Reuse of Treated Municipal Wastewater for Crop Irrigation on the Island of Crete. Agricultural Water Management, 105, 57-64.

[12] Bedbabis, S., Rouina, B.B., Boukhris, M. and Ferrara, G. (2014) Effect of Irrigation with Treated Wastewater on Soil Chemical Properties and Infiltration Rate. Journal of Environmental Management, 133, 45-50.

[13] Netzer, Y., Shenker, M. and Schwartz, A. (2014) Effects of Irrigation Using Treated Wastewater on Table Grape Vineyards: Dynamics of Sodium Accumulation in Soil and Plant. Irrigation Science, 32, 283-294.

https://doi.org/10.1007/s00271-014-0430-8

[14] Abegunrin, T.P., Awe, G.O., Idowu, D.O. and Adejumobi, M.A. (2016) Impact of Wastewater Irrigation on Soil Physico-Chemical Properties, Growth and Water Use Pattern of Two Indigenous Vegetables in Southwest Nigeria. CATENA, 139, 167178.

[15] Hamouri, B.E. and Handouf, A. (1996) Use of Wastewater for Crop Production under Arid and Saline Conditions: Yield and Hygienic Quality of the Crop and Soil Contaminations. Water Science and Technology, 33, 327-334. 
Submit or recommend next manuscript to SCIRP and we will provide best service for you:

Accepting pre-submission inquiries through Email, Facebook, LinkedIn, Twitter, etc. A wide selection of journals (inclusive of 9 subjects, more than 200 journals)

Providing 24-hour high-quality service

User-friendly online submission system

Fair and swift peer-review system

Efficient typesetting and proofreading procedure

Display of the result of downloads and visits, as well as the number of cited articles Maximum dissemination of your research work

Submit your manuscript at: http://papersubmission.scirp.org/

Or contact oje@scirp.org 